\author{
Adrian Habura \\ Uniwersytet Zielonogórski \\ ORCID: 0000-0002-6451-7290 \\ e-mail: adrianhabura12@gmail.com
}

\title{
Filozofia starożytnej Grecji w twórczości Władysława Tatarkiewicza do roku 1947 - zarys
}

Władysław Tatarkiewicz zasłynął przede wszystkim ze swojej Historii filozofii, traktatu O szczęściu, Historii estetyki i Dziejów sześciu pojęć. Treść tych czterech dzieł wpisuje się w trzy dziedziny filozoficzne, którym w swoim życiu poświęcił on najwięcej uwagi. Są to: historia filozofii, etyka i estetyka. Często łączył on te płaszczyzny: był historykiem filozofii i sztuki, ale też czerpał $\mathrm{z}$ historii w swoich oryginalnych rozważaniach etycznych i estetycznych. Choć zajmował się różnorodną problematyka, to zdaje się, że filozofia starożytna była dla niego szczególnym polem refleksji. Tatarkiewicz cenił klasyczną filozofię grecką zarówno na początku, jak i na końcu swojej drogi naukowej, traktując ją jako przedmiot dociekań, punkt wyjścia, a także źródło wzorców.

Izydora Dąmbska już w latach siedemdziesiątych sygnalizowała, że filozofia grecka zajmuje wyróżnione miejsce w twórczości Tatarkiewicza ${ }^{1}$. Mimo upływu ponad czterdziestu lat grecki szlak w jego twórczości nie został dotychczas dokładnie przebadany. Wprawdzie jego spuścizna do-

1 Por. Izydora Dąmbska, "Antyk w dziełach Władysława Tatarkiewicza", Filomata 300/301 (1976): 23-37. 
czekała się licznych opracowań, ale są to przede wszystkim krótsze teksty i cząstkowe analizy; wydanych zostało tylko kilka monografii. Tatarkiewicz był już przedstawiany m.in. jako historyk filozofii, estetyki i sztuki², a także jako aksjolog, etyk i estetyk ${ }^{3}$. Natomiast w niniejszym artykule zostanie on ukazany jako historyk filozofii greckiej i filozof korzystający z wyników pracy intelektualnej starożytnych. W związku z tym analizowana będzie przede wszystkim jego twórczość historycznofilozoficzna i filozoficzna, uwzględniona zostanie również jego biografia.

Celem artykułu jest przeglądowe zarysowanie wątku filozofii greckiej w twórczości Tatarkiewicza. Przyjęta perspektywa została jednak ograniczona do lat 1910-1947. Okres powojenny stanowi kulminację dociekań estetycznych Tatarkiewicza zarówno w perspektywie historycznej, jak i filozoficznej. Niedługo po wojnie uznał on, że do estetyki doprowadziły go dwie drogi: filozofia i historia sztuki ${ }^{4}$. Ze względu na swoją specyfikę, dominantę estetyczna, jego twórczość po roku 1947 zasługuje więc na osobne opracowanie w aspekcie odniesień do myśli i sztuki greckiej.

Strukturę niniejszego artykułu wyznacza zasadniczo chronologia prac Tatarkiewicza, a w mniejszym stopniu ich specyfika. Wątek filozofii greckiej w jego twórczości zostanie zaprezentowany na tle jego postawy badawczej, którą zgodnie z literaturą cechuje przede wszystkim: historyzm, pluralizm i semantyzm ${ }^{5}$. Historyzm jest określeniem tendencji Tatarkiewicza do rozpatrywania uniwersalnych i aktualnych problemów

2 Por. Bogdan Suchodolski, „Władysław Tatarkiewicz jako historyk filozofii”, Studia Filozoficzne 125, 4 (1976): 165-170; Alicja Kuczyńska, „Władysław Tatarkiewicz jako historyk estetyki", Studia Filozoficzne 125, 4 (1976): 93-100; Jan Białostocki, „Władysław Tatarkiewicz jako historyk sztuki”, Studia Filozoficzne 125, 4 (1976): 27-33; Czesław Głombik, Obecność filozofa. Studia historycznofilozoficzne o Władysławie Tatarkiewiczu (Katowice: Wydawnictwo Uniwersytetu Śląskiego, 2005).

3 Por. Bohdan Dziemidok, „Aksjologia Władysława Tatarkiewicza”, Filo-Sofija 11, 13-14 (2011): 459-472; Jerzy Pelc, ,'Władysław Tatarkiewicz - filozof najwyższych wartości", Studia Filozoficzne 125, 4 (1976): 87-91; Aleksandra Horecka, „Pojęcie wartości estetycznej w pracach Władysława Tatarkiewicza”, Filo-Sofija 11, 13-14 (2011): 601-615; Andrzej Książek, Piękno a sztuka. Studium pogląów estetycznych Władysława Tatarkiewicza (Warszawa: Semper, 1994); Ryszard Wiśniewski, Dobro: moralność, szczęście i piękno. Studium aksjologii Władysława Tatarkiewicza (Bydgoszcz: Oficyna Wydawnicza Epigram, 2013).

4 Por. Władysław Tatarkiewicz, Skupienie i marzenia (Kraków: Wydawnictwo M. Kot, 1951), 6.

5 Jerzy Pelc wymienia obok tych cech także systematyzm, syntetyzm i postawę psychologiczną. Por. Pelc, „,Władysław Tatarkiewicz - filozof najwyższych wartości": 90-91; por. Andrzej Książek, Tatarkiewicz (Warszawa: Wiedza Powszechna, 2010), 15-22. 
filozoficznych w perspektywie rozstrzygnięć i ujęć znanych z historii filozofii. Semantyzm u Tatarkiewicza oznacza przekonanie, że analizy znaczeniowe są kluczowe dla rozwiązywania problemów filozoficznych. Z kolei jego pluralizm, ogólnie rzecz biorąc, można zdefiniować jako przeświadczenie o złożoności, różnorodności i wieloaspektowości rzeczywistości, problemów czy osobowości, a także niechęć do zawężonych, jednostronnych ujęć zarówno filozoficznych, jak i historycznofilozoficznych. Takie przedstawienie zagadnienia ma na celu udzielenie wstępnej odpowiedzi na pytanie o znaczenie filozofii greckiej w badaniach historycznofilozoficznych i dociekaniach filozoficznych Tatarkiewicza. Można jeszcze dodać, że wszystkie te trzy cechy jego postawy badawczej, jak zostanie to ukazane w niniejszym artykule, były istotnie związane z wątkiem filozofii greckiej w jego twórczości.

Historiografia filozofii greckiej to dziedzina, w którą wpisuje się już pierwsza praca naukowa Tatarkiewicza, rozprawa doktorska opublikowana w roku 1910 pt. Die Disposition der Aristotelischen Prinzipien ${ }^{6}$. Choć filozofia arystotelesowska nie cieszyła się popularnością w Marburgu ${ }^{7}$, gdzie Tatarkiewicz studiował, to stała się ona przedmiotem jego pracy dyplomowej. Ta jego „filozoficzna niepoprawność” nie stanowiła jednak przeszkody, aby doktorat z Arystotelesa spotkał się z pozytywnymi opiniami badaczy i recenzentów ${ }^{8}$ - zresztą to od jednego z nich, Hermanna Cohena, wyszła propozycja tematu ${ }^{9}$.

6 Por. Władysław Tatarkiewicz, Die Disposition der Aristotelischen Prinzipien (Gießen: Alfred Töpelmann, 1910); w języku polskim: tenże, Układ pojęć w filozofii Arystotelesa, przeł. Izydora Dąmbska (Warszawa: Państwowe Wydawnictwo Naukowe, 1978).

7 Por. Głombik, Obecność filozofa, 27.

8 Por. Herman Cohen, „Recenzja H. Cohena dysertacji W. Tatarkiewicza: Die Disposition der Aristotelischen Prinzipien", w: Głombik, Obecność filozofa, 187-188; por. Paul Natorp, „Recenzja P. Natorpa dysertacji W. Tatarkiewicza: Die Disposition der Aristotelischen Prinzipien", w: Głombik, Obecność filozofa, 189-190; por. David Ross, „,[rec.] Die Disposition der Aristotelischen Prinzipien”, The Classical Review 24 (1910): 251.

9 Por. Władysław Tatarkiewicz, „Przedmowa”, w: Tatarkiewicz, Układ pojęć, 10; też w: Władysław Tatarkiewicz, „Wspomnienia z Marburga”, w: Szkoła marburska i jej idealizm, red. Przemysław Parszutowicz (Kęty: Wydawnictwo Marek Derewiecki, 2010), 29. W dalszej części cytowane będzie źródło najnowsze. 
Zgodnie z koncepcją tej rozprawy "tezy Arystotelesa stanowią nie jeden system (właśnie w jeden system nie dawały się ułożyć), lecz mnogość, hierarchię systemów"10. Owa hierarchia natomiast składa się z warstw lub inaczej ogniw, szczebli, stopni ${ }^{11}$ - i w tym względzie tworzy, jak pisał Tatarkiewicz, „wielopiętrową budowlę"12, w której każdy poziom „posiada własny system pojęciowy"13. Można uznać, że to funkcjonalność poznawcza warunkuje miejsce warstw w systemie, czego przykład mogą stanowić kategorie arystotelesowskie, które Tatarkiewicz postrzegał jako warstwę początkowa punkt wyjścia metody Arystotelesa, źródło podstawowej aparatury pojęciowej jego systemu filozoficznego ${ }^{14}$. Jak się wydaje, wieloaspektowość systemu filozofii arystotelesowskiej, o której Tatarkiewicz pisał doktorat, należy rozumieć właśnie w perspektywie funkcji poznawczych poszczególnych warstw. Ów pogląd Tatarkiewicza na filozofię Stagiryty najprawdopodobniej właśnie z tego powodu uznaje się za pluralistyczny ${ }^{15}$ i w tym sensie wydaje się on zalążkiem wielu jego późniejszych prac.

Jedna z nich, pt. Über die natürliche Weltansicht ${ }^{16}$, została wydana dwa lata po publikacji doktoratu $\mathrm{w}$ zbiorze prac poświęconych Cohenowi z okazji jubileuszu jego siedemdziesiątych urodzin ${ }^{17}$. Na tle innych autorów Tatarkiewicz niebywale wyróżnił się swoim tekstem, który wydaje się najmniej „marburski”"18. Można uznać, że dla swoiście platonizującej szkoły marburskiej był on niczym Arystoteles z fresku Szkoła ateńska, kierujący otwartą dłoń na ziemię. Może to obrazować nie tylko przedmiot jego refleksji, świat naturalny, ale także postawę pluralistyczną - otwarta dłoń Arystotelesa symbolizowałaby wówczas jego otwartość na wieloaspektowość rzeczywistości.

Porównując dwa obrazy świata, naturalny i naukowy, Tatarkiewicz zwrócił uwagę na znaczenie tego pierwszego dla filozofii greckiej: „na-

10 Tamże, 30.

11 Por. Władysław Tatarkiewicz, "Autoreferat”, Przegląd Filozoficzny 13, 3 (1910): 366; też w: Szkoła marburska i jej idealizm, 102. W dalszej części cytowane będzie źródło nowsze.

12 Tatarkiewicz, „Wspomnienia z Marburga”, 32.

13 Tenże, „Wstęp”, w: Tatarkiewicz, Układ pojęć, 18.

14 Por. tenże, Układ pojęć, 19-21.

15 Por. Wiśniewski, Dobro, 15-16; Dawid Lipski, „Władysława Tatarkiewicza analiza systemu filozofii Arystotelesa", Filo-Sofija 11, 13-14 (2011): 521-530.

16 Por. Tatarkiewicz, „O naturalnym obrazie świata”, w: Szkoła marburska i jej idealizm, 73-91.

17 Por. Przemysław Parszutowicz, „Tatarkiewicz i szkoła marburska”, w: Szkoła marburska i jej idealizm, 16.

18 Por. tamże, 17. 
turalny obraz świata domaga się swojej nauki o kategoriach. Ta także została de facto opracowana, a nawet odegrała $\mathrm{w}$ historii filozofii starożytnej wiodącą rolę. Przez kategorię nie należy tu jednak rozumieć już jakiejś czysto myślowej formy, lecz całkiem ogólnie - w sensie terminologii starożytnej - jakąś formę tego, co dane, jakiś typ naturalnego bytu"19. Zestawiając z kolei kategorie naturalne i naukowe, Tatarkiewicz stwierdził, że odpowiadają one „dwóm podstawowym tendencjom, które od dawna utrzymują się w filozofii: pierwsza obiera za swój obiekt świat naturalny, druga świat nauki. Jedna tendencja jest platońska, druga arystotelesowska"20. Oznacza to, że te dwa analizowane przez Tatarkiewicza obrazy świata, z których jeden został wyszczególniony w tytule, jego zdaniem zawdzięczają swój filozoficzny kształt, genezę, przede wszystkim Platonowi i Arystotelesowi.

Celem tego tekstu nie było rozstrzygnięcie, który rodzaj poznania jest lepszy. Wydaje się raczej, że intencją Tatarkiewicza było dowartościowanie poznania naturalnego jako takiego, podkreślenie jego znaczenia dla poznania naukowego ${ }^{21}$, co można uznać właśnie za wyraz jego postawy pluralistycznej i za polemikę ze szkołą marburską. Trzeci obraz świata, czyli trzecia perspektywa poznawcza, filozoficzna, został wprowadzony przez niego znacznie później w tekście pt. Droga do filozofii ${ }^{22}$. Warto także zwrócić uwage, że te pierwsze badania filozoficzne Tatarkiewicza przypominają jego historycznofilozoficzne dociekania z doktoratu, zgodnie z nimi bowiem poprzez pierwszą warstwę systemu Arystotelesa, kategorie, poznanie przechodzi od formy potocznej do złożonej, filozoficznej ${ }^{23}$, a w związku z tym pierwsza warstwa odgrywa inną rolę niż ostatnia pierwsza jest źródłowa - niemniej jednak funkcje obu są ważne dla całości systemu. Można uznać, że Tatarkiewicz postrzegał rolę naturalnego obrazu świata w poznaniu tak, jak znaczenie kategorii dla filozoficznego systemu Arystotelesa. Ukazywałoby to z kolei, że korzystał on ze swoich badań historycznofilozoficznych już w swych pierwszych oryginalnych pracach filozoficznych i w tym też względzie, zdaje się, rozwinął swoją postawę pluralistyczną.

19 Tatarkiewicz, „O naturalnym obrazie świata”, 81.

20 Tamże, 83.

21 Por. tamże, 73-75, 88, 91.

22 Por. Władysław Tatarkiewicz, „Droga do filozofii”, w: Droga do filozofii i inne rozprawy filozoficzne, red. Maria Szymaniak (Warszawa: Państwowe Wydawnictwo Naukowe, 1971), 13-52.

23 Por. Tatarkiewicz, „Autoreferat”, 102-104. 
Zdecydowanie bardziej bezpośrednio kwestię pluralizmu podjął on na gruncie estetyki w 1913 roku $^{24}$. Należy zwrócić uwagę, że sztuka towarzyszyła Tatarkiewiczowi już od najmłodszych lat ${ }^{25}$. Najprawdopodobniej w dużym stopniu, choć pośrednio, przyczyniła się do tego postać jego dziadka, rzeźbiarza klasycysty, którego życiu i twórczości Tatarkiewicz poświęcił jedną ze swoich prac naukowych ${ }^{26}$. Można więc uznać, że zarówno pluralizm, jego zalążki na gruncie badań historii filozofii, filozofii oraz estetyki, jak i wyjątkowe znaczenie kultury starożytnej, klasycznej, są dostrzegalne już we wczesnej twórczości Tatarkiewicza.

Arystoteles nie był jednak jedynym inspirującym go greckim filozofem. Tatarkiewicz swój chronologicznie pierwszy artykuł opublikował w 1911 roku i poświęcił go marburskiej interpretacji platonizmu. Był to tekst wyjątkowy, ponieważ jako jeden z pierwszych prezentował tę interpretację $\mathrm{w}$ języku polskim ${ }^{27}$. Tatarkiewicz nie zachował $\mathrm{w}$ nim jednak typowo sprawozdawczego charakteru wywodu, postanowił dokonać nawet jednoznacznego wartościowania filozofii platońskiej. W związku $\mathrm{z}$ tym w Sporze o Platona jawi się on bardziej jako marburski platonik niż badacz marburskiego platonizmu ${ }^{28}$.

W pierwszym akapicie tego artykułu stwierdził on, że historyk filozofii może zachwycać się filozofią platońska, badać ją, ale rzadko bierze ją „na serio" 29 i rozważa jako aktualną. Z kolei w zakończeniu tego tekstu Tatarkiewicz właśnie tak uczynił:

24 Por. tenże, „Streszczenie odczytu «Pluralizm w estetyce»”, Kurier Poranny 66 (1913): 4.

25 Por. „Trwanie i twórczość (rozmowa «Studiów Filozoficznych» z profesorem Władysławem Tatarkiewiczem)", Studia Filozoficzne 125, 4 (1976): 4.

26 Por. Władysław Tatarkiewicz, „Rzeźbiarz polskiego klasycyzmu Jakób Tatarkiewicz", Sztuka 3, 11-12 (1913): 195-215.

27 Por. Maciej Chlewicki, „Stulecie «Sporu o Platona»”, Filo-Sofija 13-14, 2-3 (2011): 560.

28 Por. Tomasz Mróz, „Dwa wizerunki Platona w twórczości Władysława Tatarkiewicza", Filo-Sofija 13-14, 2-3 (2011): 555. Zestawienie Sporu o Platona $\mathrm{z}$ rozdziałem z pierwszego tomu Historii filozofii poświęconym Platonowi ukazuje, że postawa Tatarkiewicza wobec filozofii platońskiej uległa pewnej transformacji na przestrzeni lat.

29 Por. Władysław Tatarkiewicz, „Spór o Platona”, Przegląd Filozoficzny 14, 3 (1911): 346; też w: Szkoła marburska i jej idealizm, 46. W dalszej części cytowane będzie źródło nowsze pod redakcją Parszutowicza. Tekst tego artykułu został także przedrukowany w antologii tekstów Platon w Polsce 1800-1950. Por. Platon w Polsce 1800-1950: antologia, red. Tomasz Mróz (Zielona Góra: Oficyna Wydawnicza Uniwersytetu Zielonogórskiego, 2010), 146-156. 
Otóż twierdzimy, że w tym platonizmie, jaki u samego Platona znajdujemy, idea jest zawsze stosunkiem pojęciowym, metoda, zasadą. I tak zrozumiany Platon jest wielkim protoplastą dzisiejszej wiedzy i filozofii; i dlatego nie tylko historyczne, ale i systematyczne zainteresowanie każe nam zwracać się ku niemu. Bo z dzieł platońskich czerpać możemy jeszcze niejedną naukę na dziś i na jutro ${ }^{30}$.

Zapewne owo przekonanie Tatarkiewicz zyskał w Marburgu, gdzie było powszechnie przyjmowane i niemal oczywiste. Na podstawie powyższych analiz można więc stwierdzić, że nie ograniczał się on do inspiracji jednym autorem czy nurtem i w związku z tym, jeśli należałoby wskazać filozofów greckich dla niego najważniejszych, to najprawdopodobniej już wówczas byli to Arystoteles i Platon.

Podsumowując dotychczasowe ustalenia dotyczące okresu marburskiego, można uznać, że z Marburga Tatarkiewicz wyniósł nawyk waloryzacji filozofii starożytnej oraz samodzielnego roztrząsania problemów filozoficznych w jej perspektywie ${ }^{31}$. Fragmenty ze Sporu o Platona stanowią pierwsze wyraźne świadectwo historyzmu Tatarkiewicza, który obok pluralizmu był drugą cechą charakterystyczną jego postawy badawczej ${ }^{32}$; choć chronologicznie i logicznie pierwsza, ponieważ jego pluralizm zdaje się wynikać właśnie z historyzmu. Te dwie postawy są więc dostrzegalne już w początkach jego działalności naukowej zarówno na gruncie badań historycznofilozoficznych, jak i filozoficznych - estetycznych, teoriopoznawczych, a z czasem także etycznych. Wraz z tymi ostatnimi semantyzm wyklarował się jako trzecia cecha charakterystyczna metodologii Tatarkiewicza, i to również nie bez związku z tradycją grecką.

Kluczowy w tym względzie był artykuł z 1919 roku pt. Pojęcie szczęścia a wymagania prawidłowej terminologii. Analizy językowe przeprowadzone przez Tatarkiewicza w tym artykule miały na celu logiczno-semantyczne uporządkowanie problematyki szczęścia ${ }^{33}$. Nie uważał on jednak, aby jego pomysł był oryginalny, wręcz odwrotnie, swoją metodę postrzegał raczej jako kontynuację tradycji:

potrzebne są badania językowe, na pozór żadnego z filozoficznymi zagadnieniami nie mające związku. Filozofowie jednak $z$ dawien dawna mieli świadomość wagi tych badań. Językowa „sztuka Prodyka”, o której mówią

30 Tatarkiewicz, „Spór o Platona”, 58.

31 Por. Głombik, Obecność filozofa, 27.

32 Por. Pelc, „Władysław Tatarkiewicz - filozof najwyższych wartości”: 90-91; por. Książek, Tatarkiewicz, 21-22.

33 Por. Władysław Tatarkiewicz, „Pojęcie szczęścia a wymagania prawidłowej terminologii", Przegląd Filozoficzny 21, 1-2 (1919): 1. 
starożytni, a zwłaszcza kunszt scholastyków w odnajdywaniu „dystynkcji” służy tej sprawie. Sprawa ta dziś bynajmniej nie jest załatwiona i nowe wysiłki będą znów musiały pójść w tym samym kierunku, co dawne sofistyczne i scholastyczne próby ${ }^{34}$.

Nie ulega zatem wątpliwości, że Tatarkiewicz inspirował się filozofią grecką na płaszczyźnie swojej metodologii również w jej aspekcie semantycznym. Artykuł ten zawiera także inne odniesienia do filozofii greckiej, które tutaj nie zostaną przywołane. Ważne jest to, że początki refleksji etycznej Tatarkiewicza są wyraźnie związane z filozofią starożytna, podejmował on bowiem problematykę bieżąca, mając na uwadze m.in. rezultaty refleksji starożytnych, ich metody oraz różnice pomiędzy filozofią grecką a współczesną.

W 1919 roku wydana została również habilitacja Tatarkiewicza pt. O bezwzględności dobra. W pewnym stopniu łączyła się ona z artykułem scharakteryzowanym powyżej, została bowiem poświęcona problematyce aksjologicznej w kontekście etycznym. Jest to praca tym ważniejsza, że Tatarkiewicz argumentował w niej za bezwzględnością dobra - czyniąc to przede wszystkim poprzez krytykę relatywizmu i subiektywizmu ${ }^{35}$ i względnością reguł postępowania, a to przekonanie z kolei stało się podstawą jego koncepcji etycznej sformułowanej w latach trzydziestych i czterdziestych. Swoje antyrelatywistyczne i antysubiektywistyczne stanowisko Tatarkiewicz wyprowadził z tradycji filozofii greckiej, wskazując Platona jako protoplastę tej postawy filozoficznej ${ }^{36}$. Choć w swojej krytyce Tatarkiewicz wpisywał się w tradycję platońska, to jednocześnie wykraczał poza nią w pozytywnym aspekcie swoich rozważań, uznając, że przedmioty posiadające bezwzględną cechę dobra nie sa, po platońsku, ponad bytem, lecz "są związane różnymi związkami z innymi przedmiotami”" ${ }^{37}$. Oznacza to, że w kwestii statusu ontycznego dobra Tatarkiewicz skłaniał się ku tradycji arystotelesowskiej ${ }^{38}$. Natomiast w perspektywie celu podjętego zadania, czyli obalenia relatywizmu i subiektywizmu etycznego, obie tradycje były dla niego inspirujące.

W klasyczną myśl starożytnej Grecji wpisują się także przykłady dobra, które przytoczył Tatarkiewicz: szlachetność, wierność, duma, piękno,

34 Tamże: $14-15$.

35 Por. Władysław Tatarkiewicz, „O bezwzględności dobra”, w: Droga do filozofii $i$ inne rozprawy filozoficzne, 265.

36 Por. tamże, 259.

37 Tamże, 266.

38 Zauważa to także Ryszard Wiśniewski (Wiśniewski, Dobro, 118-121). 
harmonia, pełnia życia, siła, radość, zdrowie ${ }^{39}$. Ważna jest również jego postawa w kwestii poznania dobra, ponieważ i tę połączył on z filozofią grecką. Uznając, że potrzebne jest przyjęcie jakiegoś stwierdzenia o dobru, które nie jest dowodzone, Tatarkiewicz zwrócił uwagę, że nie są to zdania „o konkretnych rzeczach, lecz o pewnych cechach prostych" 40 , a te „są same przez się ( «z natury») dobre"41. Owo przekonanie, że zdania etyczne bazują na zdaniach prostych i oczywistych, jako na przesłankach, wywiódł on z myśli Sokratejskiej ${ }^{42}$. Ukazuje to, że nie tylko Arystoteles i Platon, ale także Sokrates z czasem dołączył do grona myślicieli greckich inspirujących Tatarkiewicza.

Lata po opublikowaniu habilitacji to okres wytężonej pracy Tatarkiewicza i częstych zmian miejsca zatrudnienia: jesienią w 1919 roku objął on katedrę w Wilnie, w 1921 w Poznaniu, a w 1923 powrócił do Warszawy, gdzie w 1924 roku przyjął ofertę wydawnictwa Ossolińskich, które zleciło mu napisanie podręcznika do historii filozofiii ${ }^{43}$. Syn Tatarkiewicza, Krzysztof Tatarkiewicz, dokładnie relacjonuje kalkulacje swojego ojca dotyczące czasu potrzebnego na napisanie tego dzieła ${ }^{44}$. Swoje opus magnum Tatarkiewicz pisał między 1924 a 1930 rokiem. W latach dwudziestych poświęcił on filozofii greckiej najwięcej uwagi, formułując jej wykład w Historii filozofii, ale została ona przez niego w istotnym stopniu uwzględniona także w artykule z 1930 roku pt. O czterech rodzajach sadów etycznych.

Artykuł ten pozwala uznać, że filozofia grecka również wówczas była dla Tatarkiewicza źródłową inspiracją oraz punktem odniesienia. Tytułowe cztery rodzaje sądów dotyczą wartości, słuszności, moralności i zasługi ${ }^{45}$. Ich specyfikę Tatarkiewicz ukazał w związku z historycznym rozwojem problematyki moralnej. Etykę życia potocznego powiązał z sądami o wartościach, a te uznał za pierwszy rodzaj sądów etycznych, którymi według niego operowali Sokrates i Platon. Arystoteles ze swoimi sądami o słusz-

39 Por. Tatarkiewicz, „O bezwzględności dobra”, 267.

40 Tamże, 269.

41 Tamże.

42 Por. tamże, 271. Wiśniewski w swoich studiach zwrócił uwagę na sokratejskie inspiracje $\mathrm{w}$ intuicjonizmie aksjologicznym Tatarkiewicza (Wiśniewski, Dobro, 56).

43 Por. Książek, Tatarkiewicz, 78.

44 Por. Krzysztof Tatarkiewicz, „Co wiem o powstawaniu «Historii filozofii»?", w: Władysław Tatarkiewicz. W siedemdziesięciolecie I wydania "Historii filozofii", red. Czesław Głombik (Katowice: Wydawnictwo Gnome, 2003), 19-20, 23.

45 Por. Władysław Tatarkiewicz, "O czterech rodzajach sądów etycznych”, Przegląd Filozoficzny 33/4 (1930): 291; też w: Droga do filozofii i inne rozprawy filozoficzne, 290. Cytowane według wydania najnowszego. 
ności dokonał w tym względzie, jego zdaniem, rozwoju refleksji etycznej, podobnie jak etyka religijna sądami o moralności, a Kant ideą wysiłku moralnego. Wskazując na historię sądów o moralności i zasłudze, Tatarkiewicz zwrócił uwagę, że te były znane już stoikom ${ }^{46}$, a więc wszystkie wymienione przezeń rodzaje sądów były znane już w starożytności.

Nieprzypadkowo Tatarkiewicz użył zwrotu „sądy pierwszego rodzaju" 47 , chociaż „żaden z odróżnionych sądów nie może być uznany za ważniejszy i istotniejszy od innych" ${ }^{\prime 8}$, to nie są też one względem siebie równe: „trzeba posługiwać się pojęciem wartości, definiując słuszność, tak jak trzeba się odwołać do pojęcia słuszności, definiując moralność, a do pojęcia moralności - zasługę"49. Kolejność tych stopni, albo w nawiązaniu do treści doktoratu „warstw”, mająca odwzorowanie w rozwoju historycznym, ma też dla Tatarkiewicza walor praktyczny, funkcjonalny jako porządek sądzenia. Tradycja filozofii greckiej odgrywa tu więc istotną rolę - to od Sokratesa i Platona wywiódł on pierwszą fundamentalną warstwę sądów moralnych, a wszystkie cztery połączył z myślą starożytną. Zauważalne są także paralele do jego wcześniejszych prac, np. warstwowość systemu i odróżnienie obiektywności od subiektywności.

Wydane w 1931 roku dwa tomy Historii filozofii mają całkowicie inną specyfikę niż owe rozważania etyczne. W zamierzeniu miały być napisane $\mathrm{w}$ formie sprawozdawczej, co nie oznacza, że zostały pozbawione inwencji twórczej autora. W artykułach $\mathrm{z}$ dziedziny etyki filozofia grecka została wykorzystana do rozważań nad problematyką aktualną ponadczasową. Wcześniej podobnie Tatarkiewicz postąpił w habilitacji. Nawet w zestawieniu z jego doktoratem Historię filozofii cechuje już inny styl oraz cel i w związku z tym inne ujęcie filozofii greckiej. Było ono przede wszystkim sprawozdawcze, ale także zdecydowanie bardziej syntetyczne niż w którejkolwiek z jego wcześniejszych prac.

W Historii filozofii Tatarkiewicz rozwinął m.in. zagadnienia zakresu filozofii, jej dziedzin, genezy pojęcia, a także chronologii dziejów. Wskazał on, że podział dyscyplin filozoficznych na trzy główne działy w zależności od przedmiotu badan - byt, poznanie, wartości - pochodzi z Akademii Platońskiej ${ }^{50}$. Przyjął go zresztą jako schemat wykładni w Historii filozofii.

46 Por. tamże, 294.

47 Tamże, 293.

48 Tamże, 295.

49 Tamże, 293. Zależności pomiędzy rodzajami sądów przestudiował Wiśniewski (Dobro, 153-154).

50 Por. Władysław Tatarkiewicz, Historia filozofii, t. 1: Filozofia starożytna i średniowieczna (Lwów: Wydawnictwo Zakładu Narodowego im. Ossolińskich, 1933), 2. 
Podczas wyjaśniania greckiego pochodzenia nazwy „filozofia” stwierdził, że „filozofia nie od razu opanowała cały swój zakres. Dokonało się to dopiero w klasycznym okresie filozofii greckiej" 51 . Zasugerował tym samym źródłowy charakter klasycznej myśli greckiej, a w związku z tym nie dziwi fakt, że uznał Platona, nie Pitagorasa, za najważniejszego protoplastę filozofii, natomiast Arystotelesa za kontynuatora i systematyka tradycji platońskiej52. Ramy czasowe filozofii starożytnej wyznaczył na okres od VI w. p.n.e. do VI w. n.e., zauważając jednocześnie, że jest to zabieg formalny ze względu na płynność granicy między filozofią starożytną a średniowieczną ${ }^{53}$.

Ten pierwszy okres europejskiej filozofii podzielił on dodatkowo na pięć mniejszych ${ }^{54}$. Okres systemów, klasyczny, z Platonem i Arystotelesem na czele był według Tatarkiewicza fundamentalny dla historii filozofii greckiej i historii filozofii w ogóle. Zwrócił on dodatkowo uwagę na wszechstronność umysłowości greckiej już u jej zarania, jej źródłowość, a także znaczenie okresu klasycznego:

Filozofia starożytna jest filozofią grecką. [...] Właściwe greckim umysłom zainteresowanie się otaczającym światem, większe niż zainteresowanie się własną osoba, postawa śmiała, a życzliwa wobec rzeczywistości, kultura plastyczna umysłów, żądza jasności, umiłowanie rzeczy konkretnych, a jednocześnie zdolność do abstrakcyjnego rozumowania, przyczyniły się do stworzenia filozofii greckiej. Grecja rozpoczęła w VII w. pracę nad filozofia, a po dwóch stuleciach wydała już arcydzieła filozoficznej myśli, które aż do ostatnich czasów stanowią podstawę europejskiej filozofii ${ }^{55}$.

Można uznać, że zdaniem Tatarkiewicza początki filozofii greckiej stanowią trwały grunt filozofii w ogóle, który pozwolił jej zaistnieć, natomiast okres klasyczny jest jej fundamentem, na którym została ona zbudowana. Z kolei filozofia grecka jako całość jest podstawą filozofii późniejszej, która jednocześnie wykroczyła poza jej ramy.

W podsumowaniu części pierwszej Tatarkiewicz dodatkowo rozwinął tę myśl, ukazując filozofię grecką jako źródło różnorodnej problematyki filozoficznej, jako jej, można tak to ująć, typografię:

51 Tamże, 3.

52 Por. tamże.

53 Por. tamże, 4.

54 Por. tamże, 8.

55 Tamże, 7. Cechy umysłowości greckiej, które Tatarkiewicz uznał za kluczowe dla powstania filozofii, są jednocześnie tymi, które sam - zdaje się - cenił, zapewne w przekonaniu o ich aktualności. 
Starożytność, ściślej Grecja sama, wytworzyła olbrzymi zasób najróżnorodniejszych koncepcji filozoficznych; filozofię systematyczną i krytyczna, dogmatyczną i sceptyczną dualistyczny i monistyczny pogląd na świat, idealizm i realizm, wariabilizm i inwariabilizm, teizm, ateizm i panteizm, logikę pojęć i logikę zdań, w filozofii przyrody mechanizm i dynamizm, $\mathrm{w}$ teorii poznania empiryzm i aprioryzm, sensualizm i racjonalizm, w etyce moralizm i hedonizm. [...] Koncepcje, stworzone przez starożytność, zostały już na zawsze typami i wzorami dla następnych epok ${ }^{56}$.

Jako granice filozofii greckiej Tatarkiewicz wskazał konkretne postawy umysłowe: obiektywistyczna, intelektualistyczna, uniwersalistyczną i finistyczną ${ }^{57}$. Dodał również, że przezwyciężenie tych poglądów wiązało się z początkami filozofii średniowiecznej.

W kwestii historycznofilozoficznych badań Tatarkiewicza należy jeszcze dodać, że w odczycie Okresy filozofii europejskiej rozwinął on zagadnienie zależności pomiędzy epokami filozofii i jej stanowiskami ${ }^{58}$. Wymienił myślicieli, którzy, jego zdaniem, pomiędzy XV a XIX wiekiem prezentowali umysłowość antyczną. W dalszej części postanowił także odwrócić tę myśl, przedstawiając argumentację za obecnością idei nowożytnych, a dokładniej pozytywizmu, już w refleksji Protagorasa, którego, można tak to ująć, uznał za antycznego protopozytywistę ${ }^{59}$.

W latach po wydaniu Historii filozofii Tatarkiewicz podjął się również pogłębienia szczegółowej problematyki. W roku 1931 opublikował artykuł w języku francuskim, którego polska wersja ukazała się dwa lata później w "Przeglądzie Filozoficznym” pt. Trzy etyki Arystotelesa. Tatarkiewicz wspomniał ten tekst w Przedmowie do polskiego tłumaczenia swojej rozprawy doktorskiej, porównując jej rezultaty z innymi pracami na temat filozofii Arystotelesa. Nie uważał jednocześnie, że są to sprzeczne obrazy Arystotelesa, wręcz odwrotnie ${ }^{60}$. Stagiryta w artykule dotyczącym trzech modeli etycznych - etyki kontemplacji, działania (umiaru) i przyjaźni (życzliwości) - został ujęty podobnie jak w Historii filozofii, tzn. jako najrozsądniejszy z filozofów, z tą różnica, że zagadnienia etyczne zostały $\mathrm{w}$ tym artykule zdecydowanie pogłębione.

56 Tamże, 209.

57 Por. tamże, 210.

58 Por. Władysław Tatarkiewicz, „Okresy filozofii europejskiej. Odczyt inauguracyjny III Polskiego Zjazdu Filozoficznego", Kwartalnik Filozoficzny 13, 1 (1936): 267-273.

59 Por. tamże: $274-275$.

60 Por. Tatarkiewicz, „Przedmowa”, 13; tenże, „Trzy etyki Arystotelesa”, Przegląd Filozoficzny 36, 1-2 (1933): 21-22; też w: Droga do filozofii i inne rozprawy filozoficzne, 334 . 
Podsumowując, okres starożytny Tatarkiewicz wyraźnie uczynił podłożem pluralizmu w filozofii, jak i oczywiście samej filozofii. Filozofię grecką uznał za wzorzec, podstawę, źródło, punkt odniesienia dla następnych epok, postrzegał ją jako tożsamą z filozofią starożytną w ogóle oraz ukonstytuowaną przez Platona i Arystotelesa. Nie była ona jednak według niego matryca, a raczej źródłem, a może inaczej - korzeniami drzewa genealogicznego filozofii europejskiej, które trzymają ją w pionie i pozwalają jej rosnąć. Taki pogląd na filozofię starożytna, jak można mniemać na podstawie dotychczasowej analizy, rzutował na jego postawę badawczą przede wszystkim pluralizm i historyzm, ale także semantyzm.

W latach trzydziestych Tatarkiewicz powrócił również do zagadnień etycznych. Ów powrót wiąże się z krótkim tekstem pt. Dobra, których nie trzeba wybierać z 1938 roku. Zaraz na początku tej pracy zwrócił on uwagę, że aby żyć dobrze, należy posiadać zdolność oceny tego, co dobre, a co złe. Uznał w związku z tym, że sam postulat dobrego działania jest $\mathrm{w}$ tym względzie niewystarczający, istotne są jeszcze jego warunki. $Z$ tego powodu rozróżnił dobra wyższe i niższe ${ }^{61}$. Dobra, których się nie wybiera, Tatarkiewicz podzielił na dwa typy: naturalne (lub nabyte w szczególny sposób) i „osiągane na drodze umyślnego działania” ${ }^{62}$. Te drugie „są wprawdzie wynikiem działania, ale właśnie działania skierowanego ku innym celom i przedmiotom. Nie są przedmiotem wyboru, choć są wynikiem wyboru” 63 . W związku z tym stwierdził on, że "dążenie do szczęścia nie jest najlepszą drogą do zdobycia szczęścia"64. Ten oraz pozostałe artykuły dotyczące zagadnień etycznych, opublikowane przez Tatarkiewicza przed wybuchem II wojny światowej, stanowią świadectwo drogi jego rozważań etycznych zwieńczonych w 1947 roku traktatem O szczęściu.

Z jednej strony Tatarkiewicz przedstawił w nim rozważania filozofów i pisarzy na temat szczęścia, a z drugiej własne analizy i wnioski. Filozofia grecka, nie mniej niż francuska, angielska czy niemiecka, została włączona do tych rozważań. Należy przynajmniej w zarysie przedstawić, jaką rolę odgrywa ona w tym dziele, ponieważ dokładniejsze scharakteryzowanie tego zagadnienia wymagałoby osobnego opracowania.

We wstępie Tatarkiewicz podzielił rozdziały swojego traktatu ze względu na ich tematykę na: semantyczne (1-4), psychologiczne (5-13),

61 Por. tenże, „Dobra, których nie trzeba wybierać”, Kultura i Wychowanie 5, 3 (1938): 157-158; też w: Droga do filozofii i inne rozprawy filozoficzne, 312-314. W dalszej części cytowane będzie źródło nowsze.

62 Tamże, 315.

63 Tamże.

64 Tamże, 316. 
biotechniczne (14-20), etyczne (21-28) ${ }^{65}$. W każdej z tych części na różne sposoby nawiązywał do filozofii starożytnej, a z jej przedstawicieli najczęściej przywoływał Platona, Arystotelesa, Epikura i stoików. Początkowo Tatarkiewicz przyjął definicję szczęścia jako „pełne i trwałe zadowolenie z całości życia" 66 oraz rozróżnił jej aspekt idealny i realny. Doprecyzował następnie, że jest to definicja, można tak to ująć, maksymalna, idealna, a w sferze moralnej, realnej, „,szczęśliwy jest już ten, kto się do tego maximum, do tego ideału zbliża"67.

W związku z wadami tej definicji Tatarkiewicz sformułował dwie jej odmiany, jedną o charakterze subiektywistycznym, a drugą o charakterze obiektywistycznym: „Szczęściem jest trwałe, pełne i uzasadnione zadowolenie z życia. Albo: życie dające trwałe, pełne i uzasadnione zadowolenie. Są dla szczęścia te dwie formuły. [...] Nacisk kłaść można na jedno bądź drugie. Ale różnica między tymi dwoma ujęciami pojęcia szczęścia jest tylko formalna" ${ }^{68}$. Oznacza to, że człony definicji pozostają takie same, a zmianie ulega tylko jej forma i specyfika. Taki pogląd wydaje się właśnie wynikiem pluralistycznej postawy Tatarkiewicza, a w nie mniejszym stopniu jego semantycznych analiz. W związku z tym warto dodać, że Tatarkiewicz powołał się na Arystotelesa, kiedy wyszczególnił trwałość jako istotny aspekt szczęścia ${ }^{69}$. Warto zwrócić też uwagę, że mottem traktatu są właśnie słowa z Etyki nikomachejskiej ${ }^{70}$ na temat stopnia jasności rozważań etycznych, zatem także historyzm jest obecny w przyjętej przez Tatarkiewicza perspektywie.

W O szczęściu można odnaleźć jeszcze dziesiątki innych odniesień do filozofii greckiej, przykładowo są to m.in. odwołania typowo historyczno-sprawozdawcze (wskazujące źródła) ${ }^{71}$, odniesienia w perspektywie problemowej $^{72}$, a także polemika ze starożytnymi ${ }^{73}$. Wymienione formy odniesień do filozofii greckiej nie były żadnym novum w twórczości Ta-

65 Por. Władysław Tatarkiewicz, O szczęściu (Warszawa: Wiedza - Zawód Kultura, 1947), 6.

66 Tenże, O szczęściu (Warszawa: Wydawnictwo Naukowe PWN, 2015), 31; por. nieco inne sformułowanie z pierwszego wydania: tenże, O szczęściu (Warszawa: Wiedza - Zawód - Kultura, 1947), 23: „W myśl tego należałoby definiować szczęście jako: 1) zadowolenie, ale tylko 2) zupełne, 3) dotyczące całości życia i 4) stałe". W dalszej części cytowane jest wydanie pierwsze.

67 Tamże, 24.

68 Tamże, 32.

69 Por. tamże, 23.

70 Por. tamże, 4.

71 Por. tamże, 48-55.

72 Por. tamże, 219-220, 392-393.

73 Por. tamże, 254. 
tarkiewicza; posługiwał się nimi już we wcześniejszych pracach przywołanych w tym artykule. Z uwagi na specyfikę niniejszego zarysu ważne jest przede wszystkim to, że filozofia grecka z pewnością jest istotnym źródłem filozoficznych rozważań w traktacie $O$ szczęściu. Dodatkowo, uwzględniając dotychczasowe ustalenia, można traktować to dzieło jako rozwinięcie wcześniejszych refleksji Tatarkiewicza. Otwartość jego poglądu na rzeczywistość przyczyniła się zapewne do sformułowania równie otwartej koncepcji etycznej, obejmującej zarówno subiektywistyczne, jak i obiektywistyczne aspekty szczęścia, jego idealne i realne wyobrażenia, innymi słowy, wieloaspektowość rzeczywistości i różnorodność osobowości ludzkich.

Podsumowując, trzy cechy postawy badawczej Tatarkiewicza - historyzm, pluralizm, semantyzm - wydają się istotnie związane z filozofią starożytnych Greków. Pierwsze wyraźne świadectwo jego historyzmu stanowią fragmenty Sporu o Platona z 1911 roku. Z kolei zalążek pluralizmu kształtował się już wcześniej na polu historii filozofii w rozprawie doktorskiej, a niedługo później na płaszczyźnie filozoficznej w Naturalnym obrazie świata. Pluralizm był przez Tatarkiewicza rozważany również na gruncie estetyki, już w 1913 roku, co także uczynił w odniesieniu do spuścizny starożytnych. W tych pierwszych latach można też doszukiwać się początków metodologicznego semantyzmu Tatarkiewicza, już bowiem w jego doktoracie analizy językowe odgrywały kluczową rolę. Jednoznacznie zajął to stanowisko kilka lat później, kiedy przystąpił do rozważań aksjologicznych i etycznych.

Mniej lub bardziej wyraźnie Tatarkiewicz podkreślał, że podjęte przez niego zadania stanowią kontynuację tradycji greckiej - czy to sofistycznej w ramach semantyzmu, czy platońsko-arystotelesowskiej w kwestii obiektywności dobra. Przekonanie o obiektywności dobra i względności reguł postępowania, które obecne było już w habilitacji, można uznać za kluczowe dla jego koncepcji etycznej z traktatu O szczęściu. Porządek sądzenia zaproponowany przez Tatarkiewicza w roku 1930 również wydaje się istotny w tym względzie, łączy bowiem sfery obiektywności i subiektywności poprzez warstwowy system sądów moralnych, czyli konstrukt przypominający ujęcie systemu arystotelesowskiego z 1910 roku - z tą różnica, że dotyczący raczej użyteczności etycznej niż funkcjonalności poznawczej. Jednocześnie dał on w tej pracy świadectwo swojego pluralizmu, uznając w pewnym aspekcie równoważność rodzajów sądów 
etycznych, a także historyzmu, ponieważ kolejność sądzenia odpowiadała kolejności, w jakiej według Tatarkiewicza poszczególne rodzaje sądów zostały ujęte $\mathrm{w}$ dziejach filozofii starożytnej.

Owe cechy były też wyraźne w jego warsztacie historyka filozofii. Można uznać, że pluralizm w tej sferze objawił się jako metodologiczny postulat równoważności często rozbieżnych poglądów filozoficznych, czyli jako intencja bezstronności, co nie oznacza, że Tatarkiewicz nie uwzględniał interwencjonizmu badacza, wręcz odwrotnie, miał tego pełną świadomość. Semantyzm, podobnie, był punktem wyjścia zarówno w rozważaniach filozoficznych, jak i w badaniach historycznofilozoficznych. Filozofia grecka została przez Tatarkiewicza określona jako wzorzec dla czasów późniejszych, postrzegał ją jako źródłową. Okres klasyczny z Platonem i Arystotelesem na czele jawi się w jego ujęciu jako konstytuujący dla filozofii greckiej oraz filozofii w ogóle. Sokrates, Arystoteles, epikurejczycy i stoicy są ważni dla jego rozważań etycznych i choć oczywiście Platon również, to w kwestii dobra i szczęścia Tatarkiewicz bardziej sympatyzował z Arystotelesem, którego wyróżniał także na płaszczyźnie historii estetyki, twierdząc, że „żaden starożytny estetyk w tym stopniu, co Arystoteles, nie przekroczył poglądów typowo starożytnych i nie zbliżył się do typowo nowoczesnych"74. W dodatku Arystoteles był według Tatarkiewicza pluralistą estetycznym ${ }^{75}$, a więc zajmowali oni to samo stanowisko.

Wydaje się, że Tatarkiewicz był $\mathrm{w}$ istotnym stopniu myślicielem zakorzenionym $w$ duchu greckim, $w$ jego twórczości objawiło się to zainteresowaniem filozofią i kulturą grecką w ogóle, a także korzystaniem z dorobku intelektualnego Greków, użytkowaniem go w ramach autorskich dociekań filozoficznych. Świadczy o tym grecka geneza jego postawy pluralistycznej i semantycznej. Tatarkiewicz konsekwentnie afirmował filozofię grecką i greckich filozofów, a przede wszystkim Platona i Arystotelesa, których uznał nawet za najlepszych nauczycieli w kwestii szczęścia ${ }^{76}$. Filozofia grecka była zatem szczególnym źródłem odniesień oraz inspiracji Tatarkiewicza w jego badaniach i dociekaniach teoriopoznawczych, etycznych, estetycznych czy metodologicznych. Pogłębione badania ukażą skalę tych zależności, powyższe tylko niektóre $\mathrm{z}$ nich wypunktowały i scharakteryzowały.

74 Władysław Tatarkiewicz, „Dwaj nowocześni estetycy: Arystoteles i Cyceron", w: Władysław Tatarkiewicz, Droga przez estetykę, red. Alina Kozińska (Warszawa: Państwowe Wydawnictwo Naukowe, 1972), 284.

75 Por. tamże, 278.

76 Por. „Trwanie i twórczość (rozmowa «Studiów Filozoficznych» z profesorem Władysławem Tatarkiewiczem)": 13. 


\section{Bibliografia}

Białostocki Jan. 1976. „Władysław Tatarkiewicz jako historyk sztuki”. Studia Filozoficzne 125, 4: 27-33.

Chlewicki Maciej. 2011. „Stulecie «Sporu o Platona»”. Filo-Sofija 13-14, 2-3: 559-571.

Cohen Herman. 2005. „Recenzja H. Cohena dysertacji W. Tatarkiewicza: Die Disposition der Aristotelischen Prinzipien”. W: Czesław Głombik, Obecność filozofa. Studia historycznofilozoficzne o Władysławie Tatarkiewiczu, 187-188. Katowice: Wydawnictwo Uniwersytetu Śląskiego.

Dąmbska Izydora. 1976. „Antyk w dziełach Władysława Tatarkiewicza”. Filomata 300-301: 23-37.

Dziemidok Bohdan. 2011. „Aksjologia Władysława Tatarkiewicza”. Filo-Sofija 13-14, 2-3: 459-472.

Głombik Czesław. 2005. Obecność filozofa. Studia historycznofilozoficzne o Władysławie Tatarkiewiczu. Katowice: Wydawnictwo Uniwersytetu Śląskiego.

Horecka Aleksandra. 2011. „Pojęcie wartości estetycznej w pracach Władysława Tatarkiewicza". Filo-Sofija 13-14, 2-3: 601-615.

Krajewski Janusz. 1992. Władysław Tatarkiewicz. Bibliografia. Wrocław-Warszawa-Kraków: Zakład Narodowy im. Ossolińskich i Wydawnictwo Polskiej Akademii Nauk.

Książek Andrzej. 1994. Piękno a sztuka. Studium pogląów estetycznych Władysława Tatarkiewicza. Warszawa: Semper.

Książek Andrzej. 2010. Tatarkiewicz. Warszawa: Wiedza Powszechna.

Kuczyńska Alicja. 1976. „Władysław Tatarkiewicz jako historyk estetyki”. Studia Filozoficzne 125, 4: 93-100.

Lipski Dawid. 2011. „Władysława Tatarkiewicza analiza systemu filozofii Arystotelesa". Filo-Sofija 13-14, 2-3: 521-534.

Mróz Tomasz. 2011. „Dwa wizerunki Platona w twórczości Władysława Tatarkiewicza”. Filo-Sofija 13-14, 2-3: 535-557.

Natorp Paul. 2005. „Recenzja P. Natorpa dysertacji W. Tatarkiewicza: Die Disposition der Aristotelischen Prinzipien". W: Czesław Głombik, Obecność filozofa. Studia historycznofilozoficzne o Władystawie Tatarkiewiczu, 189-190. Katowice: Wydawnictwo Uniwersytetu Śląskiego.

Parszutowicz Przemysław. 2010. „Tatarkiewicz i szkoła marburska”. W: Władysław Tatarkiewicz, Szkoła marburska i jej idealizm, red. Przemysław Parszutowicz, 5-22. Kęty: Wydawnictwo Marek Derewiecki.

Pelc Jerzy. 1976. „Władysław Tatarkiewicz - filozof najwyższych wartości”. Studia Filozoficzne 125, 4: 87-91.

Ross David. 1910. „[rec.] Die Disposition der Aristotelischen Prinzipien”. The Classical Review 24: 251.

Suchodolski Bogdan. 1976. „Władysław Tatarkiewicz jako historyk filozofii”. Studia Filozoficzne 125, 4: 165-170.

Tatarkiewicz Krzysztof. 2003. „Co wiem o powstawaniu «Historii filozofii»?”. 
W: Władysław Tatarkiewicz. W siedemdziesięciolecie I wydania "Historii filozofii", red. Czesław Głombik, 19-23. Katowice: Wydawnictwo Gnome.

Tatarkiewicz Władysław. 1910. „Autoreferat”. Przegląd Filozoficzny 13, 3: 366-368.

Tatarkiewicz Władysław. 1910. Die Disposition der Aristotelischen Prinzipien. Gießen: Alfred Töpelmann.

Tatarkiewicz Władysław. 1911. „Spór o Platona”. Przeglad Filozoficzny 14, 3: 346-358.

Tatarkiewicz Władysław. 1913. „Rzeźbiarz polskiego klasycyzmu Jakób Tatarkiewicz". Sztuka 3, 11-12: 195-215.

Tatarkiewicz Władysław. 1913. „Streszczenie odczytu «Pluralizm w estetyce»”. Kurier Poranny 66: 4.

Tatarkiewicz Władysław. 1919. „Pojęcie szczęścia a wymagania prawidłowej terminologii". Przegląd Filozoficzny 21, 1-2: 1-18.

Tatarkiewicz Władysław. 1930. „O czterech rodzajach sądów etycznych”. Przegląd Filozoficzny 33, 4: 291-295.

Tatarkiewicz Władysław. 1933. Historia filozofii, t. 1: Filozofia starożytna i średniowieczna. Lwów: Wydawnictwo Zakładu Narodowego im. Ossolińskich.

Tatarkiewicz Władysław. 1933. „Trzy etyki Arystotelesa”. Przegląd Filozoficzny 36, 1-2: 13-25.

Tatarkiewicz Władysław. 1936. „Okresy filozofii europejskiej. Odczyt inauguracyjny III Polskiego Zjazdu Filozoficznego". Kwartalnik Filozoficzny 13, 1: 266-278.

Tatarkiewicz Władysław. 1938. „Dobra, których nie trzeba wybierać”. Kultura i Wychowanie 5, 3: 157-162.

Tatarkiewicz Władysław. 1947. O szczęściu. Kraków: Wiedza - Zawód - Kultura.

Tatarkiewicz Władysław. 1951. Skupienie i marzenia. Kraków: Wydawnictwo M. Kot.

Tatarkiewicz Władysław. 1971. „Dobra, których nie trzeba wybierać”. W: Droga do filozofii i inne rozprawy filozoficzne, red. Maria Szymaniak, 312-320. Warszawa: Państwowe Wydawnictwo Naukowe.

Tatarkiewicz Władysław. 1971. „Droga do filozofii”. W: Droga do filozofii i inne rozprawy filozoficzne, red. Maria Szymaniak, 13-52. Warszawa: Państwowe Wydawnictwo Naukowe.

Tatarkiewicz Władysław. 1971. „O bezwzględności dobra”. W: Droga do filozofii i inne rozprawy filozoficzne, red. Maria Szymaniak, 211-289. Warszawa: Państwowe Wydawnictwo Naukowe.

Tatarkiewicz Władysław. 1971. „O czterech rodzajach sądów etycznych”. W: Droga do filozofii i inne rozprawy filozoficzne, red. Maria Szymaniak, 290-295. Warszawa: Państwowe Wydawnictwo Naukowe.

Tatarkiewicz Władysław. 1971. „Trzy etyki Arystotelesa”. W: Droga do filozofii i inne rozprawy filozoficzne, red. Maria Szymaniak, 324-338. Warszawa: Państwowe Wydawnictwo Naukowe.

Tatarkiewicz Władysław. 1978. Układ pojęć w filozofii Arystotelesa, przeł. Izydora Dąmbska. Warszawa: Państwowe Wydawnictwo Naukowe. 
Tatarkiewicz Władysław. 1978. „Przedmowa”. W: Władysław Tatarkiewicz, Układ pojęć w filozofii Arystotelesa, przeł. Izydora Dąmbska, 5-14. Warszawa: Państwowe Wydawnictwo Naukowe.

Tatarkiewicz Władysław. 2010. „O naturalnym obrazie świata”. W: Szkoła marburska i jej idealizm, red. Przemysław Parszutowicz, 73-91. Kęty: Wydawnictwo Marek Derewiecki.

Tatarkiewicz Władysław. 2010. „Spór o Platona”. W: Szkoła marburska i jej idealizm, red. Przemysław Parszutowicz, 46-58. Kęty: Wydawnictwo Marek Derewiecki.

Tatarkiewicz Władysław. 2010. „Spór o Platona”. W: Platon w Polsce 1800-1950: antologia, red. Tomasz Mróz, 146-156. Zielona Góra: Oficyna Wydawnicza Uniwersytetu Zielonogórskiego.

Tatarkiewicz Władysław. 2010. „Wspomnienia z Marburga”, przeł. Izydora Dąmbska. W: Szkoła marburska i jej idealizm, red. Przemysław Parszutowicz, 24-33. Kęty: Wydawnictwo Marek Derewiecki.

Tatarkiewicz Władysław. 2015. O szczęściu. Warszawa: Wydawnictwo Naukowe PWN.

„Trwanie i twórczość (rozmowa «Studiów Filozoficznych» z profesorem Władysławem Tatarkiewiczem)". 1976. Studia Filozoficzne 125, 4: 3-23.

Wiśniewski Ryszard. 2013. Dobro: moralność, szczęście i piękno. Studium aksjologii Władysława Tatarkiewicza. Bydgoszcz: Oficyna Wydawnicza Epigram.

\section{Streszczenie}

Władysław Tatarkiewicz to polski uczony, historyk filozofii i filozof, który od początku swojej drogi naukowej, aż do jej końca, badał filozofię starożytnych Greków. Jego twórczość historycznofilozoficzna pozwala wnioskować, że uznawał on filozofię starożytną za fundament filozofii europejskiej, w czym - jak się wydaje - nie ma nic zaskakującego. Z kolei jego oryginalna twórczość filozoficzna świadczy o tym, że dociekania starożytnych Greków były dla niego szczególnie inspirujące. Celem artykułu jest szkicowe przedstawienie tych prac Tatarkiewicza sprzed 1947 roku, w których wątek filozofii greckiej został przez niego podjęty jako przedmiot badań historycznofilozoficznych lub jako źródło refleksji filozoficznej. Analiza twórczości zogniskowana na wątku filozofii greckiej została umieszczona w kontekście dotychczasowych badań nad metodologią Tatarkiewicza, co pozwoliło udzielić wstępnej odpowiedzi na pytanie o znaczenie antycznej filozofii greckiej dla jego rozwoju filozoficznego.

Słowa kluczowe: Władysław Tatarkiewicz, historia filozofii starożytnej, recepcja filozofii greckiej, filozofia polska 


\section{Summary}

\section{The Philosophy of Ancient Greece in the Works}

\section{of Władysław Tatarkiewicz until 1947 - an Outline}

Władysław Tatarkiewicz was a Polish scholar, a historian of philosophy, and a philosopher, who studied ancient Greek philosophy throughout his entire research career. His writings in the field of the history of philosophy allow us to conclude that he considered ancient philosophy to be the foundation of European philosophy, which does not seem surprising. Furthermore, his original philosophical works indicate that the investigations of ancient Greeks were his major inspiration. The aim of this article is to provide an outline of those of Tatarkiewicz's pre-1947 works in which Greek philosophy was explored by him as a topic of his historical research or used as the source of his original philosophical reflection. The analysis of Tatarkiewicz's works that were focused on Greek philosophy is set in the context of previous research on Tatarkiewicz's methodology, which allows us to give a preliminary answer to the question of the significance of ancient Greek philosophy for his philosophical development.

Keywords: Władysław Tatarkiewicz, ancient Greek philosophy, the reception of Greek philosophy, Polish philosophy 